\title{
Challenges of Building Information Modelling (BIM) from the Malaysian Architect's Perspective
}

\author{
Khairool Aizat Ahmad Jamal ${ }^{1, *}$, Mohammad Fadhil Mohammad ${ }^{2}$, Norfashiha Hashim², Mohamed Rizal Mohamed ${ }^{1}$ and \\ Mohd Adib Ramli ${ }^{1}$ \\ ${ }^{1}$ Faculty of Built Environment, Engineering, Technology \& Design, Taylor's University, 475oo, Selangor, Malaysia \\ ${ }^{2}$ Faculty of Architecture, Planning and Surveying, Universiti Teknologi MARA, 40450, Shah Alam, Selangor, Malaysia
}

\begin{abstract}
Malaysia is experiencing high economic growth which requires the construction industry to fulfill development demands. Building Information Modelling (BIM) had been widely publicized by the government in order to increase the industry's productivity by instigating numerous initiatives aimed to spearhead its progression. In contrast with the aspiration, architects as key players of construction industry are still facing issues in adopting BIM into practice. Previous researches had broadly covered about BIM in construction industry, but few concentrations in specific to the local architect thus imposing gap of knowledge. In addressing the issues, the research aim to probe the current state of BIM implementation, primarily on the challenges that hinders its adoption. The BIM factors which covers people, process, policy and technology were derived and investigated through the use of 322 questionnaires distributed to architects at management and operational level. The study revealed the key barriers that contributes towards the problem is within the people factor, where majority highlighted the lacked of skilled and experienced BIM workforce which contributes towards steep learning environment as well as high cost of applying BIM. Consequently, several key strategic solutions had been indicated through both external and internal factors in addressing the challenge of BIM. Results suggested that there is a need of further support from the industry's professional bodies, development of legal instruments, BIM enforcement, specific BIM education as well as BIM R\&D programs.
\end{abstract}

\section{Introduction}

Malaysian construction sector is expected to grow by at least $10.3 \%$ for year 2018. In achieving the projected growth rate, the demand for construction is estimated at RM180 billion [1]. In line with the progression, the local architectural service sector serves as one of the key players of the industry and had contributed a momentous role in the country's economic development. Presently, Building Information Modelling (BIM) is regarded as the future of the construction industry whereas the potential usage of BIM would result in greater benefits such as reducing delay of time, costs, better project coordination, increasing productivity and better control of design projects $[2,3]$. BIM is experiencing a fast expansion process through numerous initiatives and policies by public and private bodies. Hence, much efforts have been made by the government to encourage BIM development such as BIM Roadmap in March 2013, whereby the committee is setting up the benchmarking of BIM practice with three model countries for the development of the country's first BIM strategic implementation plan [4]. BIM had also become a national agenda through Construction Industry Transformation Plan (CITP) with several initiatives and mandates aimed to transform the Malaysian Construction
Industry towards stage 2 BIM maturity by 2020 [4]. However despite many benefits and efforts, Building Information Modelling (BIM) implementation in the Malaysian construction industry are still lagging behind other developing countries $[2,5]$. Based on the latest report conducted by CIDB, the BIM adoption by the construction industry players are still at an embracing level with majority of the players are experiencing low BIM usage [6].

Although architects are the leading adopters of $\mathrm{BIM}$, the amount are relatively low in view with the proportion of overall BIM adopters within the construction players is only at $17 \%$ [6]. Currently, no tangible case study or reports highlights the benefits of BIM, moreover the industry is still facing difficulties in understanding the benefits of implementing BIM into practice [6]. Although BIM had been predominantly enforced by the government, few are actually implemented BIM in their project deliverables with some of the organization had opted to outsource their BIM works rather than implementing the technology internally [7]. While annual BIM report had been the standard practice of several developing countries to report the progress of BIM implementation, it's still limited in the case of Malaysian architects, thus there is a need to further study the issues perceived in detail.

\footnotetext{
* Corresponding author: khairoolaizat.ahmadjamal@taylors.edu.my
} 


\subsection{BIM Barriers in the Construction Industry}

The Malaysian construction industry have to overcome numerous challenges in order to attain successful BIM implementation. According to UK BIM Report 2017, the implementation of BIM is comprises of several core components which is People, Process, Policy and Technology $[8,9,10]$. The transition towards BIM is not solely depending on changing of software and hardware, importantly is the socio-cultural environment that provides significant context for its implementation [10, 13]. In the context of People, [5] had stated amongst the salient factors encountered within the construction organization is the shortage of knowledgeable BIM workforce within the construction organizations. The complexity of using BIM in addition to high monetary investment are the main reasons firm's resistance on BIM. Inexperienced users may inadvertently change the content of data thus imposing risks to a project. The fragmented nature of construction project also contributes towards BIM resistance amongst the project collaborators [11]. Several technology issues had been classified, among the salient is the limited interoperability between relevant BIM software, which leads to ineffective collaboration and workflow $[12,13]$.

BIM technology often alleged as costly to be implemented and deployed $[9,10]$. The initiation of BIM requires large initial investment of cost not only to obtain the technology itself but also involves other additional costs such as training and development. In the context of Policy, [14] reported that there is unclear legal liabilities and procedures that is relevant to BIM in areas such as policies, standardize contract, ownership of data, insurance, risks and allocation of roles and responsibilities. As the allocation of rights and roles to the project were ambiguous, it is hard to accomplish smooth project progression thus imposing greater risks to the project. BIM will demand change towards an organization's working process. A fully integrated BIM model is achieve through improved communication and collaboration across disciplines. Hence, mutual protocols and standard guideline are required to assign responsibilities and executing design reviews and validation [13]. Subsequently, CIDB raised concerns on the need to develop national BIM standards and guideline to manage BIM workflow and adoption [4]. However, overlooked private firm's adoption apart from the sets intended for government projects [15]. In addition, many managers and organizational leaders lacks knowledge in adopting BIM in organization [24].

\section{Methodology}

\subsection{Research Instrument}

Questionnaire survey was used as the method of collecting data as the approach is effective in collecting objective based and measurable data, which is important for this research [25]. The questions were adopted based on review from the secondary data. The questionnaire's format is consists of four (4) sections comprising mostly closed-end questions. The first section (1) is to identify the respondent's profile and details of their participation in BIM. Section two (2) benefits of BIM, section three (3) barriers and drivers of BIM and lastly in section four (4) an open-ended question was also included to enable respondents to give personal opinions on the context of research. Prior data collection, a preliminary survey had been conducted with experienced academicians, professional architects and BIM professionals to obtain preliminary content validity for the questionnaires.

\subsection{Sampling Method}

A total of 322 survey questionnaire were sent out to the respondents in a period of one (1) month, to whom working as an architect either on behalf of architecture firm, clients or BIM consultant within the states of Malaysia. The sampling population are based from the current registrants of Malaysia Board of Architects (LAM). Currently there are 1387 Professional Architects and 760 Graduate Architects presently registered thus according to [16], the targeted sampling size for the survey was 322 respondents. Potential respondents are preferably architects with experience in BIM projects. Out of the 322 questionnaires distributed, 108 questionnaires were completed with the representation of $34 \%$. According to [17], the response rate is appropriate for a construction research.

\subsection{Demographic Profile of Respondents}

Table 1 determined to identify the respondent's role and working experience on BIM projects. In total, 108 respondents answered all questions with majority are categorized within managerial groups namely Graduate Architects (41.7\%), Senior Architects (29.6\%), Principal (9.3\%) and Associates/Directors (6.5\%). All role groups indicates high level of confidence as they are actively involved in design projects thus qualifies to answer the survey based on their experience. Majority of respondents have experience with BIM projects ranging from 1 to more than 5 years. The highest group had less than 2 years of BIM experience at $37 \%$ followed by $2-5$ years $(11.1 \%)$ and the lowest is above 5 years at $6.5 \%$. $45.4 \%$ lack experience thus indicate the trend of BIM usage within the industry is still at embracing stage.

Table 1. Respondent's Profile

\begin{tabular}{lcc}
\hline Role of Respondents & $\begin{array}{c}\text { Frequency } \\
(\mathbf{N})\end{array}$ & $\begin{array}{c}\text { Percentage } \\
(\mathbf{\%})\end{array}$ \\
\hline Principal & 10 & $9.30 \%$ \\
Associate/ Director & 7 & $6.50 \%$ \\
Senior Architect & 32 & $29.60 \%$ \\
Graduate Architect & 45 & $41.70 \%$ \\
BIM Executive & 2 & $1.90 \%$ \\
Assistant Architect & 12 & $11.10 \%$ \\
\hline BIM Experience & & \\
\hline Less than 2 years & 40 & $37.0 \%$ \\
2 to 5 years & 12 & $11.1 \%$ \\
More than 5 years & 7 & $6.5 \%$ \\
None & 49 & $45.4 \%$ \\
\hline
\end{tabular}




\section{Results and Discussions}

Table 2. Barriers of BIM Implementation

\begin{tabular}{clccc}
\hline Factors & \multicolumn{1}{c}{ BIM Barriers } & Mean & $\begin{array}{c}\text { Standard } \\
\text { Deviation (SD) }\end{array}$ & Rank \\
\hline People & Resistance towards change within the organization & 3.64 & 1.045 & 16 \\
People & Lacked of skilled and experienced BIM workforce & 4.45 & 0.778 & 1 \\
People & Clients do not demand or enforce BIM in projects & 4.06 & 1.012 & 9 \\
People & Lack enforcement by local authorities on BIM & 4.18 & 1.003 & 5 \\
People & Difficult learning curve to those unfamiliar with BIM & 4.33 & 0.875 & 2 \\
Technology & High cost of operation, hardware \& software & 4.31 & 0.942 & 3 \\
Policy & Lack of support and incentive from government and & 4.08 & 1.024 & 7 \\
& professional bodies & & & \\
Policy & Lack of training and awareness programs & 3.89 & 1.044 & 12 \\
Policy & No legal or contractual agreement on BIM & 4.02 & 0.976 & 10 \\
Policy & Unclear scope and ownership between within project team & 3.96 & 1.022 & 11 \\
Policy & Lack of best practice and guidance within industry & 3.84 & 1.120 & 13 \\
Technology & BIM lacks features or flexibility to produce 3D model & 3.67 & 1.184 & 15 \\
Technology & BIM software is difficult and complex to use & 3.60 & 1.199 & 17 \\
Technology & Issues of interoperability and data exchange & 3.58 & 1.024 & 18 \\
Technology & BIM coordination is difficult to adapt in complex design & 3.50 & 1.188 & 19 \\
Process & BIM does not reduce the time used on drafting & 3.09 & 1.250 & 20 \\
Process & Lack of active participation from consultants & 4.22 & 0.879 & 4 \\
Process & Lack of suitable BIM shared data library and standards & 3.77 & 1.149 & 14 \\
Process & Reluctance of change by consultants in project team & 4.10 & 0.896 & 6 \\
Process & Lack of BIM standard, guideline and protocols & 4.07 & 0.861 & 8 \\
\hline
\end{tabular}

\subsection{Challenges to the Implementation of BIM}

The survey determined to identify the salient barriers that hinders the adoption of BIM within the their respective practices. Respondents are required to identify the most prominent BIM barriers by selecting within the scale of agreement of ' 1 ' as most disagree and ' 5 ' as the most agreed barrier. A total of twenty (20) variables are categorized into four BIM factors (People, Technology, Process and Policy). Table 2 summarizes the overall BIM barriers based on the architect's perpectives. In overall, all respondents agreed that the most prominent challenge of BIM implementation is within the People factor. Majority of respondents agreed that the most impactful barrier is the lack of skilled and experienced BIM workforce within the industry with the mean value at 4.45 (SD 0.778).

As BIM is relatively a new technology, all respondents raised concern that BIM would impose a steep learning curve for those unfamiliar with BIM with overall mean 4.33 (SD 0.875). Both barriers have similar pace with rankings from the past researches [5, 18]. Another significant People barrier is the lack of enforcement by the local authorities with the mean value 4.18 (SD 1.003). Neighboring country such as Singapore had successfully implemented BIM in local authorities from BIM compliance to regulatory requirements with the utilization of Construction Real Estate NETwork [19]. Hence, the local public authorities need to play a significant role as currently BIM is mostly driven by the property developer and contractors [20].
Within the Process context, all respondents agreed that there is a lack of active participation from consultants in project team with the mean value at 4.22 (SD 0.879). BIM success factor is highly determined by participation, value of the model is lost due to inability to use it as intended. In relation, respondents believe that the consultants within their project team are reluctant to change to BIM (M 4.10, SD 0.896). BIM collaborative environment presents a challenge to who has the ownership of the valuable information in the model such as design information input, simulation, analysis and asbuilt BIM models [21]. Respondents also agreed that there is lack of BIM standard and guideline to define the process of BIM with the mean value at 4.07 (SD 0.861). Despite BIM had been in the market for several years, there is still no standardize BIM guideline for companies in Malaysia [22]. Importantly there is a need to have a clear plan for implementation and support for organization to fully leverage the advantages of BIM [9].

In the area of Policy, all respondents agreed that there is a lack of support from government and professional bodies such as PAM, LAM and PWD. The mean value is 4.08 (SD 1.024). To ensure a widespread adoption of BIM, the government need to take the primary role as in current, private sectors are taking the lead on BIM implementation [24]. Other barriers concerned by the respondents is there is no legal and contractual agreement on BIM with the mean value of 4.02 (SD 0.976). It was agreed that the legal and contractual relationship were among the least areas understood and will represent notable risks to the project 
team participants [23]. The most salient Technology barriers is BIM requires high cost of operation which ranked third overall (M: 4.31, SD: 0.942). As BIM requires investment of equipment, software, hardware and training, it would greatly impact on cost. In previous researches, cost was highlighted as main factor that hinders the adoption of BIM [18, 21, 24].

\subsection{Strategic Solutions of BIM Implementation}

Table 3. External BIM Strategic Solutions

\begin{tabular}{|c|c|c|}
\hline Strategic Solutions (External) & Mean & SD \\
\hline $\begin{array}{l}\text { Demand in sustainable design \& } \\
\text { construction }\end{array}$ & 4.26 & 0.836 \\
\hline BIM education and certifications & 4.48 & 0.767 \\
\hline $\begin{array}{l}\text { Promotion and awareness by } \\
\text { industry's contributors }\end{array}$ & 4.34 & 0.738 \\
\hline $\begin{array}{l}\text { Support from professional bodies } \\
\text { (LAM, PAM) }\end{array}$ & 4.51 & 0.704 \\
\hline BIM R\&D collaborations & 4.43 & 0.700 \\
\hline $\begin{array}{l}\text { Development of BIM standard legal } \\
\text { or contractual agreement }\end{array}$ & 4.25 & 0.822 \\
\hline BIM enforcement from clients & 4.40 & 0.785 \\
\hline $\begin{array}{l}\text { Government BIM support and } \\
\text { enforcement }\end{array}$ & 4.43 & 0.726 \\
\hline $\begin{array}{l}\text { Specialization of design services } \\
\text { towards BIM }\end{array}$ & 4.23 & 0.860 \\
\hline Effects of globalization & 4.25 & 0.822 \\
\hline Design build and fast track projects & 4.38 & 0.817 \\
\hline $\begin{array}{l}\text { Technical progress in computing \& IT } \\
\text { technologies }\end{array}$ & 4.30 & 0.788 \\
\hline Development of BIM standards & 4.29 & 0.786 \\
\hline Enhancement of BIM tools & 4.31 & 0.719 \\
\hline
\end{tabular}

Table 4. Internal BIM Strategic Solutions

\begin{tabular}{lcc}
\hline Strategic Solutions (Internal) & Mean & SD \\
\hline $\begin{array}{l}\text { Enhancing roles and responsibilities } \\
\begin{array}{l}\text { Investment in BIM training \& } \\
\text { development }\end{array}\end{array}$ & 4.34 & 0.751 \\
$\begin{array}{l}\text { Leadership \& vision of top } \\
\text { management }\end{array}$ & 4.54 & 0.742 \\
$\begin{array}{l}\text { Establish BIM organizational } \\
\text { structure }\end{array}$ & 4.45 & 0.715 \\
$\begin{array}{l}\text { Investment of BIM softwares and } \\
\text { hardware }\end{array}$ & 4.35 & 0.715 \\
$\begin{array}{l}\text { Standard BIM workflow within } \\
\text { organization }\end{array}$ & 4.46 & 0.674 \\
$\begin{array}{l}\text { Enhancing BIM legal \& ownership } \\
\text { agreement }\end{array}$ & 4.29 & 0.854 \\
$\begin{array}{l}\text { Developing BIM execution plan } \\
\text { Competitiveness of business } \\
\text { environment }\end{array}$ & 4.31 & 0.742 \\
$\begin{array}{l}\text { BIM software and interoperability } \\
\text { Quality of softwares available }\end{array}$ & 4.24 & 0.841 \\
Employing BIM specialists & 4.33 & 0.749 \\
\hline
\end{tabular}

In order to find the most impactful solutions, the research further narrowed the scope to the most salient drivers as perceived by the Malaysian architects. The questionnaire had listed 14 external factors and 12 internal factors of BIM strategic solutions, consequently five most important solutions have been identified for each factors. Table 3 \& 4 summarizes the overall strategic solutions according to related driving factors. Within the external factor, all respondents agreed the first factor that would increase the pace of BIM is by gaining support from the profession's bodies such as CIDB, LAM and PAM (M: 4.51, SD: 0.74). Another important solution is to enhance BIM education and awareness within the architecture profession with overall means 4.48 (SD: 0.767). Thirdly is to further involve cooperation from the government bodies in providing support as well as enforcing BIM in design projects (M: 4.43, SD: 0.726$)$. The findings from this solution are in line with several past studies whereas the enforcement of BIM by the government can help to increase BIM practices in construction projects [15]. Among the key steps being introduce by the government is to mandate BIM implementation for government projects. Further to that all respondents agreed that there is a need for public and private bodies to conduct further BIM research and development (M: 4.43, SD: 0.700). BIM enforcement by the clients are also important aspect in spearheading the implementation of BIM (M: 4.40, SD: 0.785).

Further to this, all respondents agreed that investment in BIM training and development by organization as the most important factors within the internal factor. The high cost of training is amongst the salient hindering factor of BIM implementation. At present CIDB through MyBIM Centre is actively providing BIM trainings and courses to prepare the industry for implementation as well other training sources from local BIM consultant companies [6, 7]. Ranked at the second place is the need for BIM standard and workflow within their organization. Nearly half of the respondents $(44.40 \%)$ agreed that the BIM industry should be standardize in terms of standard and workflow. All respondents also agreed that the leadership and strategic vision of top management plays an important role towards BIM implementation (M: 4.45, SD: 0.715). Furthermore, majority of the respondents choose to establish BIM organizational structure as the fourth strategic solution in improving the BIM industry with mean value at 4.44 (SD: 0.715). The investment of software and hardware are also an important internal solutions (M: 4.35, SD 0.674).

\section{Conclusion}

BIM had proven to be an effective technology with numerous studies had highlighted its potential capabilities. However in the context of Malaysian architecture industry, the implementation are still in slow pace. Several factors that hinders the adoption of BIM had been identified (1) Lack of skilled and experienced 
workforce, (2) Steep learning curve for especially for those who are unfamiliar with BIM and (3) High cost to obtain and operate the technology. As the government is looking to initiate BIM stage 2, it is vital that the salient challenges are to be addressed for the improvement of the Malaysian architecture industry. Therefore, continuous supports from the organization's external as well as internal environment are significant to increase the pace of BIM implementation in the Malaysian architecture industry. Finally, several limitations need to be acknowledged. In general the time constraint and relatively small sample sizes may lead to concerns on generalization.

\section{References}

1. CIDB, Malaysia Country Report, $22^{\text {nd }}$ AsiaCons. Conf. (2014)

2. Gardezi, Safdar, S. Shujaa, N. Shafiq, M.F. Nurudinn, S.A. Farhan, U.A. Umar, Challenges for Implementation of Building Information Modeling (BIM) in Malaysian Construction Industry, App. Mech. \& Mat. 567 (2014)

3. Lahdou, Rim, D. Zetterman, BIM for Project Managers How project managers can utilize BIM in construction projects (2011)

4. CIDB, Workshop report (series 2) of building information modelling (BIM) roadmap for Malaysia's construction industry, Report. CIDB (2015)

5. Zakaria, Z., et al. Exploring the barriers and driving factors in implementing building information modelling (BIM) in the Malaysian construction industry: A preliminary study, J. Ins. of Eng. Mal. (2013)

6. CIDB, Malaysia building information modelling report 2016, CIDB Mal. (2017)

7. M.F.I. Mohd-Nor, M.P. Grant, Building information modelling (BIM) in the Malaysian architecture industry, WSEAS Tran. On Env. And Dev. 10, 264-273 (2014)

8. NBS, NBS National BIM Report 2017. London, RIBA Ent. Ltd. (2017)

9. C. Eastman, P. Teicholz, R. Sacks, K. Liston, BIM Handbook: A Guide to Building Information Modelling (BIM) for Owners, Managers, Designers, Engineers and Constructions. Wiley (2011)

10. Smith, K. Dana, M. Tardif, Building information modeling: a strategic implementation guide for architects, engineers, constructors, and real estate asset managers. John Wiley \& Sons (2009)

11. A. Nanajkar, Implementing Building Information Modeling (BIM) at AEC Firms in India (2014)

12. A.H. Memon, I.A. Rahman, I. Memon, N.I.A. Azman, BIM in Malaysian construction industry: status, advantages, barriers and strategies to enhance the implementation level, Res. J. of Appl. Sci., Eng. and Tech., 8(5), 606614 (2014)

13. K. Kensek, D. Noble, Building information modeling: BIM in current and future practice. John Wiley \& Sons (2014)

14. K.F. Chien, Z.H. Wu, S.C. Huang, Identifying and assessing critical risk factors for BIM projects: Empirical study, Auto. in Cons. 45, 115 (2014)

15. A.A. Latiffi, S. Mohd, U.S. Rakiman, Potential improvement of building information modeling (BIM) implementation in malaysian construction projects. IFIP Int. Conf. on Prod. Lifec. Manag., Springer, 149-158 (2015)

16. Krejcie, V. Robert, D.W. Morgan, Determining sample size for research activities, Edu. and Psych. Measure. 30.3 607-610 (1970)

17. Jin, Ruoyu, et al. An empirical study of perceptions towards construction and demolition waste recycling and reuse in China, Res., Conserv., and Recyc. 126, 86-98 (2017)

18. K. Ku, M. Taiebat, BIM experiences and expectations: the constructor's perspective, Int. J. of Cons. Edu. and Res. 7(3), 175-197 (2011)

19. A.N. Harun, S.A. Samad, M.N. Mohd Nawi, N.A. Haron, Existing Practices of Building Information Modeling (BIM) Implementation in the Public Sector, Int. J. of Supp. Ch. Manag. 5(4), 166-177 (2016)

20. Construction, M. H. Smart Market report: the business value of BIM for construction in major global markets, Retrieved form McGraw-Hill Construction website (2014)

21. S. Talebi, Exploring advantages and challenges of adaptation and implementation of BIM in project life cycle, $2^{\text {nd }}$ BIM Int. Conf. on Chal. to Overcome. BIMForum Portugal, (2014)

22. M.H. Hanafi, G.G. Sing, S. Abdullah, R. Ismail, Organisational Readiness of Building Information Modelling Implementation: Architectural Practice. J. Tek., 78(5), 121-126 (2016)

23. J. Rogers, H.Y. Chong, C. Preece, Adoption of building information modelling technology (BIM) perspectives from Malaysian engineering consulting services firms, Eng., Cons. and Arch. Manag., 22(4), 424-445 (2015)

24. Z. Zahrizan, N. Mohamed Ali, A. Tarmizi Haron, A.J. Marshall-Ponting, Z. Abd Hamid, Exploring the adoption of Building Information Modelling (BIM) in the Malaysian construction industry: A qualitative approach, Int. J. of Res. in Eng. and Tech. 2(8), 384-395 (2013)

25. Creswell, J. W., \& Creswell, J. D, Research design: Qualitative, quantitative, and mixed methods approaches. Sage publications (2017) 